\title{
Involvement of equine chorionic gonadotropin (eCG) carbohydrate side chains in its bioactivity; lessons from recombinant hormone expressed in insect cells
}

\author{
Sébastien Legardinier, Claire CAHOREAU, Danièle KLETT, \\ Yves COMBARNOUS*

\begin{abstract}
Unité de Physiologie de la Reproduction et des Comportements, Institut National de la Recherche Agronomique (INRA), Centre National de la Recherche Scientifique (CNRS) et Université François Rabelais de Tours, 37380 Nouzilly, France
\end{abstract}

\begin{abstract}
Natural eCG consists of as much as $45 \%$ carbohydrate side chains. The present paper deals with the analysis of the roles of the $\mathrm{N}$ - and O-linked saccharides of this hormone in the different steps of its activity and its possible repacement by recombinant eCG expressed in baculovirus - insect cell systems.
\end{abstract}

half-life / gonadotropin / carbohydrate / recombinant hormone / baculovirus

\section{INTRODUCTION}

Equine chorionic gonadotropin (eCG) formerly named pregnant mare serum gonadotropin (PMSG) belongs to the family of glycoprotein hormones. It is produced by trophoblast cells of endometrial cups in pregnant mares and plays a major role in the maintenance of early gestation [1]. As the other members of the family including luteinizing hormone $(\mathrm{LH})$, follicle-stimulating hormone (FSH) and thyroid stimulating hormone (TSH), eCG is composed of two dissimilar and noncovalently associated $\alpha$-and $\beta$-subunits. Within the same species, the $\alpha$-subunit is encoded by a single gene and is common to all glycoprotein hormones whereas different genes encode $\beta$-subunits, which confer specificity to the glycoprotein hormone heterodimers $[2,3]$. In horses, in contrast to primates, both $\mathrm{LH}$ and CG $\beta$-subunits are encoded by the same gene [4] and consequently the recombinant hormone is called eLH/CG. Both placental
eCG and pituitary eLH exhibit dual LH and FSH in non equine species with identical FSH/LH activity ratios [5]. Although eCG and eLH exhibit identical $\alpha$ and $\beta$ polypeptide chains, their carbohydrate contents are different. Indeed, eCG is the most heavily glycosylated of all glycoprotein hormones with $45 \%$ carbohydrate by weight versus $30 \%$ for eLH. The $\alpha$-subunit, composed of 96 amino acids, bears two complex-type $\mathrm{N}$-linked oligosaccharide chains located at asparagines (Asn) 56 and 82 whereas the $\beta$-subunit composed of 149 amino acids has only one at Asn 13. In addition to N-glycans, both eLH and eCG $\beta$-subunits possess a carboxy-terminal peptide (CTP) of 29 amino acids ( $\beta 121-149)$, which is O-glycosylated at the same twelve serine or threonine residues [6]. Placental and pituitary hormones also strongly differ by their N-glycan termination with sialic acids (Siao2, $3 \mathrm{Gal}$ ) on eCG and sulfated N-acetylgalactosamines $\left(\mathrm{SO}_{4}-4-\mathrm{GalNac}\right)$ in eLH $[7,8]$.

* Corresponding author: combarno@tours.inra.fr 

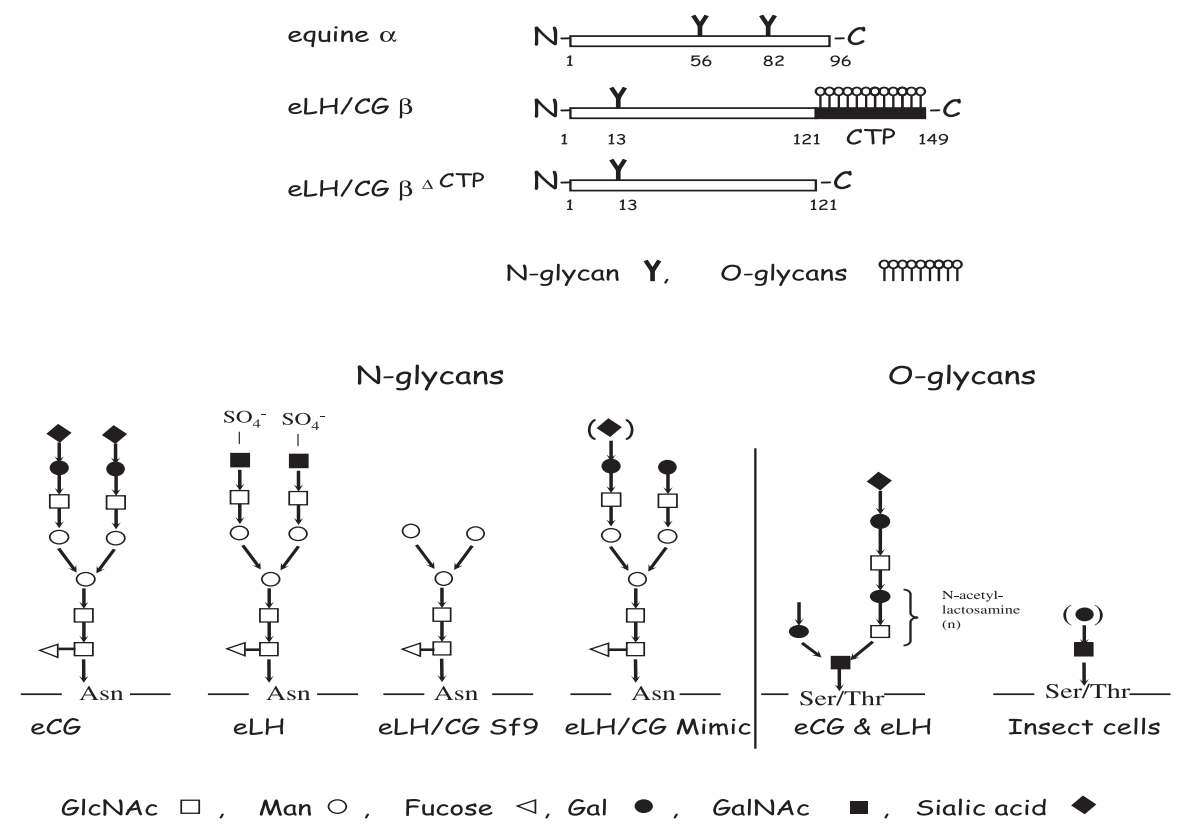

Figure 1. Positions and structures of carbohydrate chains of equine gonadotropins. Upper panel: Positions of $\mathrm{N}$ - and O-glycans in the $\alpha$ - and $\beta$-subunit of eLH and eCG, and in the recombinant $\beta$-subunit lacking its CTP. Lower panel: Typical structures of $\mathrm{N}$-carbohydrate side chains (left) and $\mathrm{O}$-carbohydrate side chains (right) of natural eCG and eLH and of recombinant $\mathrm{eLH} / \mathrm{CG}$ expressed in Sf9 and Mimik cell lines respectively. In O-glycans, the number of N-acetyl-lactosaminyl motifs (n) is much larger in eCG than in eLH.

The remarkable difference in their molecular weight is essentially due to the presence of longer disialylated poly-N-acetyllactosaminyl O-glycans on eCG with a greater percentage of O-glycans attached at serine and threonine sites [6,9] (Fig. 1). These structural differences explain why eCG has such an exceptional half-life compared to eLH. Owing to its biological properties, eCG has been used for a long time in fertilization programs. Nevertheless, commercial preparations of partially purified eCG from pregnant mare sera (PMSG) could contain contaminants with potential sanitary risks.

It is of great interest to produce in large quantities a bioactive substitute for eCG and other gonadotropins used as therapeutic agents. Only recombinant gonadotropins produced in mammalian cells have been shown so far to exhibit in vivo biological activity. Such hormones like hFSH expressed in CHO cells [10] have even been put on the market (Gonal-F ${ }^{\circledR}$ Serono, Geneva, Switzerland; Puregon ${ }^{\circledR}$ NV Organon, Oss, The Netherlands). However, the great advantage of non-mammalian systems like yeasts, insect cell lines or plants would be to produce recombinant proteins in large amounts, at a lower cost, and in the absence of fetal calf serum. Some gonadotropins of zootechnical interest have already been expressed in baculovirus systems [11-14], but also in the methylotropic yeast Pichia pastoris [15-17], and in plants [18]. However, only in vitro biological activities have been reported in these studies with no information concerning in vivo potencies.

Recently, single-chain eLH/CG [19] and bFSH [20] have been produced in milk of transgenic rabbits. In vivo biological activity was determined only for eLH/CG, and it was found to be inactive because of its 
too-short half-life, likely because the carbohydrate moieties of recombinant glycoproteins in milk [21] are unusual compared to those found in serum glycoproteins.

In three recent papers we have described the long half-life of natural eCG in rats [22], the production of recombinant eLH/CG by Sf9 cells and Mimic cells and compared the biological [23] and structural [24] properties of these hormones with those of natural $\mathrm{eLH}$ and eCG.

\section{TOMOGRAPHIC STUDY OF ECG HALF-LIFE}

In contrast to ${ }^{123} \mathrm{I}-\mathrm{pLH}$ that is trapped by kidneys in less than $5 \mathrm{~min}$ time, ${ }^{123} \mathrm{I}-\mathrm{eCG}$ remains in the circulation over hours in the rat [22]. This huge difference is due to the higher molecular weight and negative charge of eCG that impedes its glomerular filtration. The acidic nature of eCG is due in large part to its high sialic acid content and therefore, this point must be taken into account in the production of recombinant eCG.

\section{BIOLOGICAL PROPERTIES OF RECOMBINANT ECG EXPRESSED IN BACULOVIRUS- INSECT CELL SYSTEMS}

This expression system allows a high level of production of recombinant protein but $\mathrm{N}$-glycans processed in insect cells such as $\mathrm{Sf} 9$ cells are not complex and sialylated $\mathrm{N}$-glycans such as those found in placental eCG. However, the in vivo biological activity of eCG strongly depends on the presence of sialylated complex saccharidic chains on protein. To overcome this problem, we expressed recombinant eLH/CG in Mimic $^{\mathrm{TM}}$ cells that had been claimed to produce biantennary, terminally sialylated $\mathrm{N}$-glycans. Equine CG possesses extensive Nand O-glycosylation with $45 \%$ of its mass due to its carbohydrate moiety. In addition to the complex sialylated biantennary $\mathrm{N}$ glycans [7], eCG possess twelve uncommon disialylated poly-(N-acetyllactosamine)
$\mathrm{O}$-glycans located at the $\mathrm{C}$-terminus of the $\beta$-subunit $[6,9]$.

In Sf9 cells, N-glycans consist of paucimannose structures with or without fucose residues linked to the chitobiose core. However, some insect cell lines like Estigmene acrea Ea4 cells possess low levels of $\mathrm{N}$ acetyl- $\beta$-glucosaminidase leading to $\mathrm{N}$-glycans with non-reducing terminal $\mathrm{N}$-acetylglucosamine residues and others like Trichoplusia ni (TN-5B1-4, High Five) cells may possess a low level of galactosyltransferase activity [25]. Although having a low N-glycosylation potential, Sf9 cells have the advantage of synthesizing no immunogenic glycans in contrast to Trichoplusia ni cells in which immunogenic $\alpha 1$-3-fucose linkages are found [26].

Recombinant eLH/CG and its subunits expressed in Sf9 cells and in Mimic ${ }^{\mathrm{TM}}$ cells exhibited lower apparent molecular weights compared to mare plasma eCG and its subunits, highlighting the presence of shorter glycans in these cells. Nevertheless, the higher apparent molecular weights found for $\mathrm{eLH} / \mathrm{CG}$ and its subunits expressed in Mimic $^{\mathrm{TM}}$ cells compared to $\mathrm{Sf} 9$ cells strongly suggest that glycosylation was indeed improved. The major differences in MW between natural and recombinant hormones seem to be essentially due to very short O-glycans on the CTP domain of eLH/CG produced in insect cells.

Both eLH/CG expressed in Sf9 and Mim$\mathrm{ic}^{\mathrm{TM}}$ cells exhibited full in vitro $\mathrm{LH}$ and $\mathrm{FSH}$ bioactivities confirming that recombinant hormones possess a conformation similar to that of natural eCG. Equine $\mathrm{LH} / \mathrm{CG}$ expressed in Mimic ${ }^{\mathrm{TM}}$ cells and Sf9 cells exhibit in vitro $\mathrm{FSH} / \mathrm{LH}$ ratios that are not significantly different. By contrast, both recombinant $\mathrm{eLH} / \mathrm{CG}$ exhibit no in vivo biological activity. Even recombinant eLH/ CG produced in Mimic ${ }^{\mathrm{TM}}$ cells was found to be inactive in the FSH in vivo bioassay of Steelman and Pohley, which does not require a hormone with a very long half-life as in the eCG in vivo bioassay of Cole and Erway. The absence of in vivo bioactivity 
of recombinant eLH/CG might be the result of a rapid clearance of the hormone in the plasma as is the case for single-chain eLH/ CG expressed in the milk of transgenic rabbits [19]. Sialic acids are mainly responsible for a prolonged half-life in plasma suggesting they are partially or totally lacking on eLH/CG produced in Sf9 cells and in Mimic $^{\mathrm{TM}}$ cells. Native eLH is known to bear sulfated $\mathrm{N}$-glycans and sialylated $\mathrm{O}$ glycans. Although displaying similar in vitro $\mathrm{FSH} / \mathrm{LH}$ ratios, native $\mathrm{eLH}$, which bears less sialic acids compared to eCG, exhibits a much shorter half life. The presence of sialylated O-glycans is also involved in the half-life since the elimination of the O-glycosylated CTP from hCG led to a drastic decrease of its half-life [27].

\section{BIOCHEMICAL PROPERTIES OF RECOMBINANT ECG EXPRESSED IN BACULOVIRUS- INSECT CELL SYSTEMS}

Natural and recombinant eCG $\alpha$-subunits were found to be $\mathrm{N}$-glycosylated since their hydrolysis with PNGase F led to proteins with lower apparent MW that were not recognized by Concanavalin A. Sf9 cells produce glycoprotein hormone with $\mathrm{N}$-oligomannosidic structures, whereas Mimic ${ }^{\mathrm{TM}}$ cells elaborate complex-type N-glycans bearing terminal galactose without any sialylation. Lectin analyses also show the presence of O-linked oligosaccharidic chains on recombinant subunits and $\mathrm{eLH} / \mathrm{CG}$ secreted by Sf9 and Mimic ${ }^{\mathrm{TM}}$ cells, with a GalNAcGal disaccharide structure (Legardinier et al, submitted) as previously shown for insect or recombinant glycoproteins expressed in Sf9 and other insect cell lines [28, 29].

\section{CONCLUSIONS}

Two strategies can be proposed to engineer $\mathrm{N}$ - and $\mathrm{O}$-glycosylation; one by modifying the cell genome of insect cells and the other by introducing all needed glycosyltransferase genes in the baculovirus genome. Recently, a new transgenic insect cell line
(SfSWT3) was described [30], that corresponds to the transformation of Mimic ${ }^{\mathrm{TM}}$ cells (SfSWT1) with two additional mammalian genes encoding a sialic acid synthase and CMP-sialic acid synthase. It has been claimed to correctly sialylate a recombinant glycoprotein on its two antennary Ncarbohydrate chains in the absence of fetal bovine serum and could thus be of great interest in the production of active recombinant gonadotropins.

Another approach will be to construct transgenic viruses containing the genes encoding eCG subunits together with all required glycosidase and glycosyltransferase genes.

\section{REFERENCES}

[1] Allen WR, Moor RM. The origin of the equine endometrial cups. I. Production of PMSG by fetal trophoblast cells. J Reprod Fertil, 1972, 29: 313-316.

[2] Pierce JG, Parsons TF. Glycoprotein hormones: structure and function. Annu Rev Biochem 1982, 50: 465-495.

[3] Combarnous Y. Molecular basis of the specificity of binding of glycoprotein hormones to their receptors. Endocr Rev 1992, 13: 670-691.

[4] Sherman GB, Wolfe MW, Farmerie TA, Clay CM, Threadgill DS, Sharp DC, Nilson JH. A single gene encodes the beta-subunits of equine luteinizing hormone and chorionic gonadotropin. Mol Endocrinol 1992, 6: 951-959.

[5] Combarnous Y, Guillou F, Martinat N. Comparison of in vitro follicle-stimulating hormone (FSH) activity of equine gonadotropins (luteinizing hormone, FSH, and chorionic gonadotropin) in male and female rats. Endocrinology 1984, 115: 1821-1827.

[6] Bousfield GR, Butnev VY. Identification of twelve O-glycosylation sites in equine chorionic gonadotropin beta and equine luteinizing hormone ss by solid-phase Edman degradation. Biol Reprod 2001, 64: 136-147.

[7] Smith PL, Bousfield GR, Kumar S, Fiete D, Baenziger JU. Equine lutropin and chorionic gonadotropin bear oligosaccharides terminating with SO4-4-GalNAc and Sia alpha 2,3Gal, respectively. J Biol Chem 1993, 268: 795802.

[8] Matsui T, Mizuochi T, Titani K, Okinaga T, Hoshi M, Bousfield GR, Sugino H, Ward DN. Structural analysis of N-linked oligosaccharides of equine chorionic gonadotropin and lutropin beta-subunits. Biochemistry 1994, 33: 14039-14048. 
[9] Hokke CH, Roosenboom MJ, Thomas-Oates JE, Kamerling JP, Vliegenthart JF. Structure determination of the disialylated poly- $(\mathrm{N}$ acetyllactosamine)- containing O-linked carbohydrate chains of equine chorionic gonadotropin. Glycoconj J 1994, 11: 35-41.

[10] Keene JL, Matzuk MM, Otani T, Fauser BC, Galway AB, Hsueh AJ, Boime I. Expression of biologically active human follitropin in Chinese hamster ovary cells. J Biol Chem 1989, 264: 4769-4775.

[11] Inaba T, Mori J, Ohmura M, Tani H, Kato Y, Tomizawa K, Kato T, Ihara T, Sato I, Ueda S. Recombinant porcine follicle stimulating hormone produced in baculovirus-insect cells induces rat ovulation in vivo and gene expression of tissue plasminogen activator in vitro. Res Vet Sci 1998, 64: 25-29.

[12] Huang CJ, Huang FL, Chang GD, Chang YS, Lo CF, Fraser MJ, Lo TB. Expression of two forms of carp gonadotropin alpha subunit in insect cells by recombinant baculovirus. Proc Natl Acad Sci USA 1991, 88: 7486-7490.

[13] Kato Y, Sato I, Ihara T, Tomizawa K, Mori J, Geshi M, Nagai T, Okuda K, Kato T, Ueda S. Expression and purification of biologically active porcine follicle- stimulating hormone in insect cells bearing a baculovirus vector. $\mathrm{J}$ Mol Endocrinol 1998, 20: 55-65.

[14] van de Wiel DF, van Rijn PA, Meloen RH, Moormann RJ. High-level expression of biologically active recombinant bovine follicle stimulating hormone in a baculovirus system. J Mol Endocrinol 1998, 20: 83-98.

[15] Fidler AE, Lun S, Young W, McNatty KP. Expression and secretion of a biologically active glycoprotein hormone, ovine follicle stimulating hormone, by Pichia pastoris. J Mol Endocrinol 1998, 21: 327-336.

[16] Richard F, Robert P, Remy JJ, Martinat N, Bidart JM, Salesse R, Combarnous Y. Highlevel secretion of biologically active recombinant porcine follicle-stimulating hormone by the methylotrophic yeast Pichia pastoris. Biochem Biophys Res Commun 1998, 245: 847-852.

[17] Fidler AE, Lin JS, Lun S, Ng Chie W, Western A, Stent V, McNatty KP. Production of biologically active tethered ovine FSHbetaalpha by the methylotrophic yeast Pichia pastoris. J Mol Endocrinol 2003, 30: 213-225.

[18] Dirnberger D, Steinkellner H, Abdennebi L, Remy JJ, van de Wiel D. Secretion of biologically active glycoforms of bovine follicle stimulating hormone in plants. Eur J Biochem 2001, 268: 4570-4579.

[19] Galet C, Le Bourhis CM, Chopineau M, Le Griec G, Perrin A, Magallon T, Attal J, Viglietta C, Houdebine LM, Guillou F. Expression of a single betaalpha chain protein of equine $\mathrm{LH} /$ CG in milk of transgenic rabbits and its bio- logical activity. Mol Cell Endocrinol 2001, 174: 31-40.

[20] Coulibaly S, Besenfelder U, Miller I, Zinovieva N, Lassnig C, Kotler T, Jameson JL, Gemeiner M, Muller M, Brem G. Expression and characterization of functional recombinant bovine follicle-stimulating hormone (boFSHalpha/beta) produced in the milk of transgenic rabbits. Mol Reprod Dev 2002, 63: 300-308.

[21] Koles K, van Berkel PHC, Mannesse MLM, Zoetemelk R, Vliegenthart JFG, Kamerling JP. Influence of lactation parameters on the $\mathrm{N}$-glycosylation of recombinant human $\mathrm{C} 1$ inhibitor isolated from the milk of transgenic rabbits. Glycobiology 2004, 14: 979-986.

[22] Klett D, Bernard S, Lecompte F, Leroux H, Magallon T, Locatelli A, Lepape A, Combarnous Y. Fast renal trapping of porcine luteinizing hormone $(\mathrm{pLH})$ shown by $123 \mathrm{I}-$ scintigraphic imaging in rats explains its short circulatory half-life. Reprod Biol Endocrinol 2003, 1: 64.

[23] Legardinier S, Duonor-Cerutti M, Devauchelle G, Combarnous Y, Cahoreau C. Biological activities of recombinant equine luteinizing hormone/chorionic gonadotropin (eLH/CG) expressed in Sf9 and Mimic insect cell lines. J Mol Endocrinol 2005, 34: 47-60.

[24] Legardinier S, Klett D, Poirier JC, Combarnous Y, Cahoreau C. Mammalian-like non-sialyl complex-type N-glycosylation of equine gonadotropins in Mimic ${ }^{\text {TM }}$ insect cells. Glycobiology 2005 , in press.

[25] Altmann F, Staudacher E, Wilson IB, Marz L. Insect cells as hosts for the expression of recombinant glycoproteins. Glycoconj J 1999, 16: 109-123.

[26] Hsu TA, Takahashi N, Tsukamoto Y, Kato K, Shimada I, Masuda K, Whiteley EM, Fan JQ, Lee YC, Betenbaugh MJ. Differential N-glycan patterns of secreted and intracellular IgG produced in Trichoplusia ni cells. J Biol Chem 1997, 272: 9062-9070.

[27] Matzuk MM, Hsueh AJ, Lapolt P, Tsafriri A, J. Keene JL, Boime I. The biological role of the carboxyl-terminal extension of human chorionic gonadotropin [corrected] beta-subunit. Endocrinology 1990, 126: 376-383.

[28] Lopez M, Tetaert D, Juliant S, Gazon M, Cerutti M, Verbert A, Delannoy P. O-glycosylation potential of lepidopteran insect cell lines. Biochim Biophys Acta 1999, 1427: 49-61.

[29] Thomsen DR, Post LE, Elhammer AP. Structure of O-glycosidically linked oligosaccharides Synthesized by the insect cell line Sf9. J Cell Biochem, 1990, 43: 67-79.

[30] Aumiller JJ, Hollister JR, Jarvis DL. A transgenic insect cell line engineered to produce CMP-sialic acid and sialylated glycoproteins. Glycobiology 2003, 13: 497-507. 